\title{
Prevalence of deep vein thrombosis in patients with paraplegia caused by traumas
}

\author{
Prevalência de trombose venosa profunda em paraplégicos de causa traumática
}

\author{
Nelson Mesquita Junior ${ }^{1,2}$, Flávia Natalia Marques Kingerski ${ }^{1,2}$, Giovana Liz Marioto, ${ }^{1,2}$, \\ Fábio Alex Fonseca Viegas², Suzelaine Fidelis da Silva Mesquita³, Sônia Perreto ${ }^{3}$
}

\begin{abstract}
Background: Deep vein thrombosis is a common disease among people who are immobilized. Immobility is inherent to paraplegia and leads to venous stasis, which is one of the factors covered by Virchow's triad describing its development. Trauma is the primary cause of paraplegia and is currently increasing at a rate of $4 \%$ per year. Objective: To determine the prevalence of deep vein thrombosis in paraplegic patients whose paraplegia was caused by traumas, using color Doppler ultrasonography for diagnosis. Methods: This was a cross-sectional observational study of 30 trauma-induced paraplegia patients, selected after analysis of medical records at the neurosurgery department of a University Hospital in Curitiba, Brazil, and by a proactive survey of associations that care for the physically disabled. The prevalence of deep vein thrombosis was analyzed using 95\% confidence intervals. Results: Spinal cord trauma was the cause of paraplegia in 29 patients. The most common cause of trauma was gunshot wounding, reported by 17 patients. Deep vein thrombosis was diagnosed by color Doppler ultrasonography in 14 patients in the sample. The most often affected vein was the posterior tibial, in 11 patients. The left lower limb was involved three times more often than the right. Edema was observed in 25 individuals, cyanosis in 14, ulcers in 8 and localized increase in temperature in 13. Conclusions: Deep vein thrombosis was prevalent, occurring in $46.7 \%$ of the patients.
\end{abstract}

Keywords: deep vein thrombosis; paraplegia; immobilization.

\begin{abstract}
Resumo
Contexto: A trombose venosa profunda é uma doença comum em indivíduos imobilizados. A imobilização, inerente aos pacientes paraplégicos, gera a estase venosa, que é um dos fatores descritos da tríade de Virchow para o seu desenvolvimento. O trauma é a principal causa de paraplegia e, atualmente, vem aumentando a uma taxa de $4 \%$ ao ano. Objetivo: Avaliar a prevalência de trombose venosa profunda em paraplégicos, em que o trauma foi o agente causal da paraplegia, utilizando como método diagnóstico o eco Doppler colorido. Métodos: Estudo observacional transversal, composto por 30 pacientes paraplégicos por trauma, selecionados segundo uma análise de prontuários do Serviço de Neurocirurgia de um Hospital Universitário de Curitiba e por busca ativa em associações de assistência aos deficientes físicos. A análise da prevalência de trombose venosa profunda foi efetuada pelo intervalo de confiança de 95\%. Resultados: O traumatismo raquimedular foi a causa da paraplegia em 29 pacientes. A causa mais frequente do trauma foi o ferimento por arma de fogo, relatado por 17 pacientes. A presença de trombose venosa profunda diagnosticada por eco Doppler colorido foi observada em 14 pacientes da amostra. Dentre estes, a veia mais acometida foi a tibial posterior, em 11 pacientes. O membro inferior esquerdo foi três vezes mais acometido que o direito. $\mathrm{O}$ edema foi observado em 25 indivíduos, a cianose em 14, a úlcera em oito e o aumento de temperatura local em 13. Conclusão: A trombose venosa profunda foi prevalente, ocorrendo em 46,7\% dos pacientes.
\end{abstract}

Palavras-chave: trombose venosa profunda; paraplegia; imobilização.

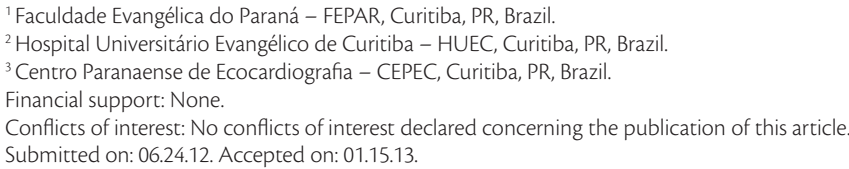




\section{INTRODUCTION}

Venous thromboembolism (VTE) includes two conditions: deep vein thrombosis (DVT) and pulmonary embolism (PE). Although they are different diseases, both are manifestations of the same dynamic process, since DVT is the principal cause of PE, which, in turn, may be the first clinical presentation of DVT. VTE is extremely important because of its elevated frequency and high rates of morbidity and mortality ${ }^{1,2}$.

Virchow's triad can be used to analyze the origins of VTE. Venous stasis, endothelial injury and hypercoagulability are the factors involved in its pathogenesis whether in conjunction or in isolation ${ }^{3}$.

Deep vein thrombosis is the formation of thrombi in veins of the deep venous system causing total or partial occlusion ${ }^{1}$. In the acute phase it can be associated with severe and potentially fatal complications and PE is the most serious acute complication. Chronic DVT patients can develop postthrombotic syndrome, which plays a role in the incapacitating sequelae of chronic venous insufficiency and the high socioeconomic costs of this process ${ }^{4}$.

In the United States of America, it is estimated that DVT affects $1 \%$ of the population each year and it is the third most common cardiovascular disease there ${ }^{2}$.

A range of factors related to Virchow's triad predispose patients to DVT, in particular prior thromboembolic disease, major surgery, multiple trauma, neoplasms, sepsis, oral contraceptive use and vasculitis ${ }^{5}$. Recognition of these clinical conditions is important both for diagnosis and for choosing the most appropriate prophylactic or therapeutic course of action.

Clinical diagnosis of DVT is imprecise because just $30-50 \%$ of cases present with typical signs and symptoms ${ }^{6}$. In view of this, supplementary tests are of fundamental importance to confirming or ruling out this diagnosis?

Color Doppler ultrasonography (CDU) is an effective noninvasive examination for morphological and functional analysis of the venous segment of interest ${ }^{8}$. Deep vein thrombosis is a disease with high prevalence among immobilized patients, as has been well-documented in the literature ${ }^{9}$. Prolonged periods immobile in bed cause venous stasis in the lower limbs, which is a condition that has been identified as increasing the risk of acquired hypercoagulability states, which can lead to DVT ${ }^{9}$. However, there are few reports of the prevalence of VTE among paraplegic patients who were injured by traumas. It is assumed that paraplegia secondary to trauma is also a condition that predisposes to DVT since the venous stasis that is inherent to the immobile state is present, combined or not with endothelial injuries and hypercoagulability.

Currently, trauma is the number one cause of paraplegia. A study by Gehrig \& Michaelis found that the number of cases of posttraumatic paraplegia have been increasing at a rate of $4 \%$ per year ${ }^{10}$. In Brazil, approximately 11,304 people become paraplegic or tetraplegic each year ${ }^{11}$.

Studies report that spinal cord injury (SCI) is the greatest cause of morbidity and mortality among young adults aged from 18 to 35 , at a proportion of four male victims for every female, and traffic accidents, falls and violence are the primary causes ${ }^{12}$. It is estimated that more than 10,000 new cases of spinal injury occur every year in Brazil, and they are predominantly caused by traumas ${ }^{13}$.

Spinal cord injuries strike healthy people at the peak of their working capacity and, since they are also severe conditions, are common and cause irreversible sequelae, they constitute a public health problem ${ }^{14}$. In view of this, it is of fundamental importance that prophylaxis, treatment and motor rehabilitation of these patients be managed appropriately.

In view of the absence of studies in the literature correlating DVT with paraplegia, the objective of this study is to investigate the prevalence of DVT among paraplegic patients whose paraplegia was caused by trauma, employing CDU scans for diagnosis.

\section{METHODOLOGY}

The research project was designed between March and August of 2010 and approved by the Research Ethics Committee under protocol number 8355/10 on 13th September of the same year.

This study was conducted at a neurology and neurosurgery department and at three associations that care for the physically disabled.

The sample was chosen at random and comprised the first 30 first patients who met the inclusion criterion.

The inclusion criterion was paraplegia caused by trauma with day to day locomotion dependent on wheelchair use.

The 30 participants were selected using a threestage process. Initially, 5,451 medical records were analyzed and 268 candidates were preselected. Thirteen of these patients met the inclusion criterion. In order to complete the sample an active search was conducted at associations that care for the physically disabled, yielding a further 17 participants. 
Data collection was conducted from October to December of 2010.

Each participant was interviewed and, after signing a consent form, answered a questionnaire. After the interview, CDU scans of the lower extremities were conducted at a specialized diagnostic imaging center.

Criteria used to evaluate the CDU findings and diagnose DVT were venous occlusion, noncompressible deep vein segments and indirect signs of historic deep vein thrombosis (thickening of the vein wall, reflux and intraluminal lesions).

Vessel walls were assessed and the presence of intraluminal material and degree of compressibility were investigated using B mode. Color mode was used to assess flow and/or reflux and spectral mode was used to evaluate respiratory phasicity, the waveform pattern and the duration of reflux, when present.

The great majority of data analysis was descriptive. Statistics were used to analyze the prevalence of DVT and the prevalence of posterior tibial vein involvement. Analysis of the prevalence of DVT in the sample of paraplegic patients studied was conducted using a $95 \%$ confidence interval. The prevalence of thrombosis in the posterior tibial vein was analyzed in the same manner.

\section{RESULTS}

The study population comprised 30 paraplegic patients whose paraplegia had been caused by traumas. Ages ranged from 18 to 56 and mean age was 32.9 years. Sex distribution was $28(93.3 \%)$ men and $2(6.7 \%)$ women.

The length of time elapsed since the trauma varied from 1 to 38 years.

The causes of traumas were gunshot wounds in 17 cases (56.7\%), traffic accidents in seven (23.3\%), falls from height in two (6.7\%), diving into shallow waters in two $(6.7 \%)$, crushing in one $(3.3 \%)$ and physical aggression in one case (3.3\%). Paraplegia was due to SCI in $29(96.7 \%)$ of the 30 patients and was the result of cranial-encephalic trauma in one case $(3.3 \%)$.

Fourteen of the patients assessed $(46.7 \%)$ exhibited the sequelae of DVT or presence of venous occlusion. It can be inferred on the basis of this that the percentage of paraplegic patients with DVT in the population is from $28.8 \%$ to $64.5 \%$, within a $95 \%$ confidence interval.

Deep vein thrombosis was bilateral in six cases and unilateral in eight. Where unilateral, the left lower limb was three times more prevalent than the right, as illustrated in Figure 1.
Over half of the patients with DVT (57.1\%) had involvement of more than one territory and $35.7 \%$ had just one involved territory, with the most common being the infra-popliteal segment, as shown in Figure 2. The vein with greatest incidence was the posterior tibial, which was involved in $11(78.6 \%)$ of 14 cases, making it possible to infer with $95 \%$ confidence that the percentage of paraplegic patients in the population with DVT at this site is in the range from 57.1 to $100 \%$.

As shown in Table 1, the clinical signs investigated were edema, cyanosis, ulcer and increase in local temperature. Signs were considered positive if they had occurred at any point since the traumatic event, irrespective of whether they were present or not when the questionnaire was administered. It should also be pointed out that any given patient may exhibit more than one clinical sign. Edema was observed in 25 of the 30 patients, cyanosis in 14 , ulcers in eight and high localized temperatures in 13 .

\section{DISCUSSION}

Deep vein thrombosis has multifactorial origins that have their bases in Virchow's triad, which was

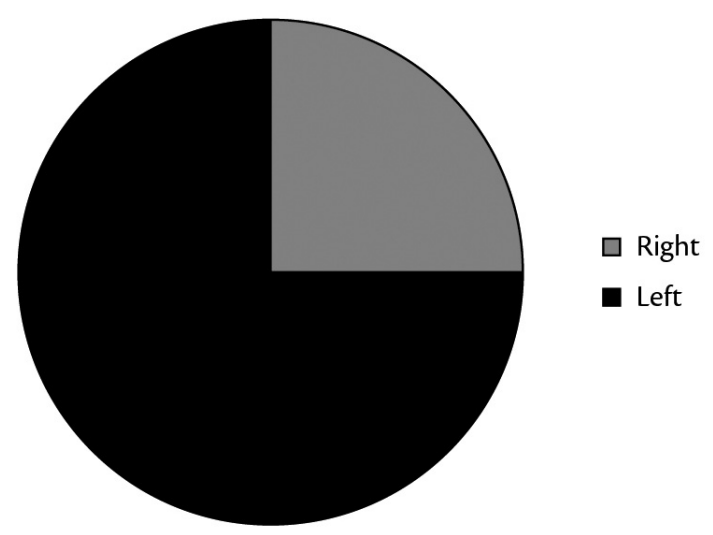

Figure 1. Distribution of unilateral deep vein thrombosis.

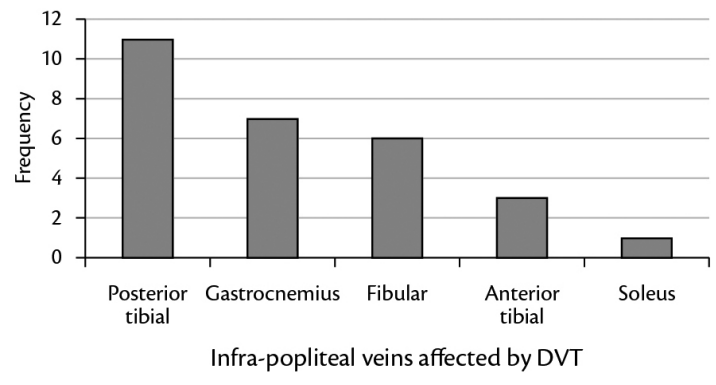

Figure 2. Distribution of deep vein thrombosis in infrapopliteal vascular territory. 
Table 1. Clinical signs of DVT in the study population (patients with deep vein thrombosis $n=14$; patients without deep vein thrombosis $n=16$ ).

\begin{tabular}{ccccc}
\hline DVT & EDEMA & CYANOSIS & ULCERS & HIGH TEMPERATURE \\
\hline YES & $92.9 \%$ & $50 \%$ & $42.3 \%$ & $35.8 \%$ \\
NO & $75 \%$ & $43.8 \%$ & $12.5 \%$ & $50 \%$ \\
\hline
\end{tabular}

described in $1856^{15}$. One hundred and fifty years later, the statement remains true and understanding of the relative roles of each of these factors has made it possible to understand thrombotic phenomena, allowing for diagnosis and identification of people at increased risk, thereby aiding in rational management of these patients ${ }^{16}$.

According to Penha et al., venous stasis is considered the principal factor predisposing to $\mathrm{DVT}^{17}$. Situations that restrict movement lead to loss of calf muscle pump function and consequent venous stasis of lower limbs, which is one of the most important factors that has been identified as responsible for thrombogenesis ${ }^{17,18}$. In our study, immobility was a risk factor that was inherent to all participants, since the sample comprised 30 paraplegic individuals who had been the victims of traumas.

Spinal cord injuries were the principal cause of paraplegia in our sample (96.7\%). This is a highly incapacitating condition, since spinal cord patients have a high incidence of related morbidity, suffer multiple and prolonged hospitalizations and have a mortality rate of $4.4 \%$ to $16.7 \%$ during the first hospital stay alone ${ }^{19,20}$. The social and psychological impact of this condition is clear, whether on patients or their families, in addition to the financial repercussions for the healthcare systems that treat and rehabilitate these patients. It is believed that US $\$ 4$ billion are spent annually in the United States on treating traumatic spinal cord injuries and their consequences $^{21}$.

In terms of incidence rates, it is estimated that more than 12 thousand spinal cord injuries occur every year in the United States, which is 11.5 new cases per million inhabitants annually. The majority of these cases are the result of injuries sustained from firearms or in traffic accidents ${ }^{22}$. In Brazil, the estimated annual incidence of spinal cord injury due to trauma is 22.6 new cases per million inhabitants ${ }^{14,23,24}$. Traffic accidents, falls from height, accidents involving diving in shallow water and gunshot wounds are the primary causes of SCI. Our study was conducted in the city of Curitiba, which is a large urban center and gunshot wounds were the number one cause $(56.7 \%)$, followed by traffic accidents $(23.3 \%)$ and falls from height $(6.7 \%)$. These figures are in line with results reported by Hughes, who has shown that the frequency of SCI caused by gunshot wounds has increased considerably, reflecting the high level of violence in large urban centers ${ }^{25}$.

According to the literature, spinal cord injury predominantly affects males, at a ratio of $4: 1$, and an age range of 15 to $40^{26}$. In agreement with these data, the mean age in this study was 32.9 and $93.3 \%$ were men.

In contrast with other studies ${ }^{27}$, few patients were over the age of 40 and the majority were younger. This can be explained by the fact that traumas are more common among the young, as mentioned earlier.

With regard to DVT, it should be remembered that they are a serious complication in patients with SCI.

It has been shown that out of all causes of hospital admission, patients with spinal cord injuries in the acute phase are at greatest risk of developing $\mathrm{DVT}^{27}$. The reduced vasomotor tonus, venous return and muscle contraction combined with hypercoagulability, immobility and direct damage to the deep venous system all predispose patients with SCI in the acute phase to $\mathrm{DVT}^{28}$.

The incidence of DVT during the first 3 months of paralysis secondary to spinal cord injury is $38 \%{ }^{1}$, peaking between 7 and 10 days $^{29}$, although rates vary from 9 to $90 \%$ depending on the diagnostic methods used in studies ${ }^{30}$. In our study, $46.7 \%$ of the patients exhibited the sequelae of DVT and calculation of the confidence interval allowed for the inference that the percentage of paraplegic patients who have had DVT in the population is between $28.8 \%$ and $64.5 \%$. The time taken for DVT to emerge after paraplegia was not investigated and diagnoses were considered positive when CDU scans showed sequelae of venous thrombi or venous occlusion. The time elapsed since trauma was covered by the questionnaire and varied from 1 to 38 years.

Diagnosis of DVT on the basis of symptoms and clinical signs offers little precision and has high rates of both false-positives and false-negatives. Fortes et al. have stated that clinical diagnosis of DVT is imprecise, since just 20 to $40 \%$ of patients with symptoms suggestive of DVT actually have the disease confirmed by objective examinations. On the other hand, 15 to $50 \%$ of DVT cases do not initially present with a characteristic clinical status ${ }^{7}$. 
The reason for this confusing range of presentations is that even large thrombi can obstruct $10 \%$ to $40 \%$ of the lumen of the involved vein, without causing clinical manifestations.

In our study, the clinical signs investigated with relation to DVT were edema, cyanosis, ulcers and increased temperature in the affected limb. Edema was the most common sign, but it was equally present in people who had and had not had the disease. As can be seen in Table 1, in general these clinical signs were present in similar proportions in patients who exhibited the disease and in patients who did not. It can therefore be concluded that these signs are indeed imprecise and nonspecific, as is shown by the literature, and it is not possible to diagnose DVT merely on the basis of clinical manifestations. This means that diagnostic certainty is dependent on supplementary tests ${ }^{7}$.

Although some authors consider phlebography to be the gold standard for diagnosis of DVT, the method suffers form certain limitations. Phlebography is contraindicated in patients who have allergic reactions to the contrast, have kidney disorders or are pregnant, and it is also expensive ${ }^{31}$.

Noninvasive investigation of lower limb veins using CDU has proved of fundamental importance for diagnosis of DVT. This examination can be used to determine patency of vein segments, to trace the anatomy of the superficial and deep venous system and communicating veins to evaluate the characteristics of venous flow and to measure the caliber of vessels, in addition to its role in identifying possible origins of emboligenesis and reflux ${ }^{32}$. Meissner ${ }^{33}$ describes CDU as a good method for investigation of DVT and Zierler ${ }^{34}$ has observed sensitivity and specificity of $95 \%$ for cases of DVT in symptomatic patients. Zierler claims that CDU is currently the examination of choice for diagnostic investigation of DVT in the lower extremities, whether in proximal or distal segments. It is a noninvasive examination, it does not employ ionizing radiation or ionic contrast and it is reproducible and inexpensive ${ }^{35}$.

In the study described here, CDU was chosen for diagnostic imaging because according to the literature it is currently the most recommended method for investigating presence of DVT. Additionally, although some authors consider phlebography to be the gold standard, it is being substituted by CDU because it is an invasive examination and suffers from some important contraindications.

With regard to the vascular territories investigated for signs of DVT, it should be pointed out that the deep vein system was analyzed and that this is responsible for around $90 \%$ of lower extremity venous drainage. For the purposes of instruction, lower extremity venous drainage was subdivided into three territories: the iliac-femoral (common iliac, external iliac, femoral and profunda femoralis veins), the popliteal (popliteal vein) and the infrapopliteal (anterior and posterior tibial, fibular, gastrocnemius and soleus veins), as shown in Table 1. The infrapopliteal territory was most often involved among those patients who exhibited signs of DVT, as illustrated in Figure 2. This finding is in line with results published by Kearon ${ }^{36}$, who reports that the majority of DVT cases have their origins in the infrapopliteal veins, in particularly the muscular veins. Sevitt and Gallagher ${ }^{37}$ also found that the most common site of DVT was the infrapopliteal veins, and in their study the intramuscular veins of the calf were involved in $74 \%$ of cases. These authors were also the first to report that the soleus veins are the most common site of DVT. In contrast, the most often involved vein in our study was the posterior tibial, which was affected in eleven of the fourteen patients who had the disease. It is therefore possible to infer, with $95 \%$ confidence, that the percentage of paraplegic patients in the population with DVT at this site is between $57.1 \%$ and $100 \%$.

Melo et al. report that DVT is more common in the left lower limb than in the right ${ }^{38}$. This is due to compression of the left common iliac vein by the right common iliac artery ${ }^{31}$. The same result was observed among the patients in our sample, since involvement of the left lower limb was three times more prevalent than involvement of the contralateral limb.

\section{CONCLUSIONS}

Analyzing the data from this study, it can be observed that DVT was prevalent, being present in $46.7 \%$ of the sample. In Brazil, as in other countries, there are few published studies of the epidemiology of VTE in paraplegic patients. The results show that these patients should be seen as at high risk of development of VTE, and so mechanical prophylaxis should be initiated early, since immobility is a condition that leads to loss of function of the calf muscle pump, nullifying the most important hemodynamic mechanism for prevention of venous stasis in lower limbs. Permanent pharmaceutical prophylaxis is a possibility that should be considered with these patients. The data collected in this study could be of importance to alert treating physicians to the need for permanent prophylaxis against VTE in paraplegic patients. 


\section{REFERENCES}

1. Rocha AT. Tromboembolismo venoso: profilaxia em pacientes clínicos - parte I. Associação Médica Brasileira e Conselho federal de Medicina; 2005. Projeto Diretrizes. [citado 2011 abr. 05]. http:// www.projetodiretrizes.org.br/4_volume/37-tramboembolismopartel.pdf.

2. Caiafa JS, Bastos M. Programa de profilaxia do tromboembolismo venoso do Hospital Naval Marcílio Dias: um modelo de educação continuada. J Vasc Bras. 2002;1:103-12.

3. Baruzzi ACA, Nussvacher A, Lagudis S, Souza JAM. Trombose venosa profunda: profilaxia. Arq Bras Cardiol. 1996;67(3): 215-8.

4. Schreiber D. Deep venous thrombosis and thrombophlebitis. Medscape. [citado 2011 maio 11]. http://emedicine.medscape.com.

5. Keane MG, Ingenito EP, Goldhaber SZ. Utilization of venous thromboembolism prophylaxis in the medical intensive care unit. Chest. 1994;106:13-4. http://dx.doi.org/10.1378/chest.106.1.13

6. Maffei FHA. Epidemiologia da trombose venosa profunda e de suas complicações no Brasil. Cir Vasc Angiol. 1998;14:5-8.

7. Fortes VB, Rollo HA, Fortes AT Jr, et al. Avaliação do modelo de predição clínica de Wells no diagnóstico da trombose venosa profunda dos membros inferiores. J Vasc Bras. 2007;6(1):7-16. http://dx.doi.org/10.1590/S1677-54492007000100003

8. Patel K, Feied C. Deep Venous Thrombosis. Medscape. [citado 2011 abr. 13]. http://emedicine.medscape.com.

9. Barreto SSM, Silva PM, Faccin CS, Theil AL, Nunes $A H$, Pinheiro CTS. Profilaxia para tromboembolia venosa em uma unidade de tratamento intensivo. J Pneumol. 2000;26(1):15-9. [citado 2011 mar. 19]. http://www.jornaldepneumologia.com. br/PDF/2000_26_1_4_portugues.pdf.

10. Gehrig R, Michaelis LS. Statistics of acute paraplegia and tetraplegia on a national scale. Spinal Cord. 1968;6:93-5. http:// dx.doi.org/10.1038/sc.1968.16

11. Mansini $M$. Estimativa da Incidência e Prevalência de Lesão Medular no Brasil. J Bras Neurocirurg. 2001;12(2):97-100.

12. Waters RL, Adkins RH. Firearm versus motor vehicle related spinal cord injury: preinjury factors, injury characteristics, and initial outcome comparisons among ethnically diverse groups. Arch Phys Med Rehabil. 1997;78(2):150-5. http://dx.doi.org/10.1016/ S0003-9993(97)90256-2

13. Mansini M. Tratamento das fraturas e luxações da coluna toracolombar por descompressão póstero-lateral e fixação posterior com retângulo e fios segmentares sublaminares associados a enxerto ósseo. [Tese]. São Paulo: Universidade Federal de São Paulo, Escola Paulista de Medicina; 2000. p. 112.

14. Freitas PEP. Traumatismos Raquimedulares Agudos: estudo epidemiológico de cem casos consecutivos. J Bras Neurocir. 1990;2(1):1-10.

15. Garcia ACF, Souza BV, Volpato DE, et al. Realidade do uso da profilaxia para trombose venosa profunda: da teoria à prática. J Vasc Bras. 2005;4(1):35-41. [citado 2011 ago. 12]. http://www. jvascbr.com.br/05-04-01/05-04-01-35/05-04-01-35.pdf.

16. Lourenço DM. Alterações da hemostasia que propiciam o tromboembolismo venoso. Cir Vasc Angiol. 1998;14:9-15.

17. Penha GS, Damiano AP, Carvalho T, Lain V, Serafim JD. Mobilização precoce na fase aguda da trombose venosa profunda de membros inferiores. J Vasc Bras. 2009;8(1):77-85. http://dx.doi.org/10.1590/ S1677-54492009000100011

18. Guimarães Jl. Diretriz da embolia pulmonar. Arq Bras Cardiol. 2004;83(1):1-8. [citado 2011 maio 10]. http://publicacoes. cardiol.br/consenso/2004/EmboliaPulmonar.pdf.
19. Amaral SH, Silva MN, Viterbo MBS, Giraldi $M$, Pereira CAB. Fisiopatologia do traumatismo raquimedular. Uma revisão. Arq Bras Neurocir. 2008;21(3):83-9. [citado 2011 mar. 25]. http://sbn. com.br/files/downloads/publicacoes/arquivos-brasileiros-deneurocirurgia/arqbrneuro27_3.pdf.

20. Heinemann AW, Yarkony GM, Roth EJ, et al. Functional outcome following spinal cord injury. A comparison of specialized spinal cord injury center vs general hospital short-term care. Arch Neurol. 1989;46:1098-1102. http://dx.doi.org/10.1001/ archneur.1989.00520460084017

21. Stripling TE. The cost of economic consequences of traumatic spinal cord injury. Paraplegia News. 1990;8:50-4.

22. Ho CH, Wuermser LA, Priebe MM, Chiodo AE, Scelza WM Kirshblum SC. Spinal cord injury medicine. Epidemiology and classification. Arch Phys Med Rehabil. 2007;88(3 Suppl 1):S49-54. http://dx.doi.org/10.1016/j.apmr.2006.12.001

23. Botelho RV, Abgussen CMB, Machado GCFP, et al. Epidemiologia do trauma raquimedular cervical na zona norte da cidade de São Paulo. Arq Bras Neurocir. 2001;20:64-76.

24. Cunha FM, Menezes CM, Guimarães EP. Lesões traumáticas da coluna torácica e lombar. Rev Bras Ortop. 2000;35:17-22.

25. Hughes JT. The Edwin Smith Surgical Papyrus: an analysis of the first case reports of spinal cord injuries. Paraplegia. 1988;26:71-82. http://dx.doi.org/10.1038/sc.1988.15

26. Pereira UC, Carvalho LFP, Santos EAS. Complicações clínicas do traumatismo raquimedular: pulmonares, cardiovasculares, geniturinárias e gastrintestinais. Arq Bras Neurocir. 2010; 29(3):110-7. [citado 2011 jan. 07]. http://www. sbn.com.br/files/downloads/publicacoes/arquivos-brasileirosde-neurocirurgia/arqbrneuro29_3.pdf.

27. Geerts WH, Bergqvist D, Pineo GF, et al. Prevention of venous thromboembolism: American College of Chest Physicians Evidence-Based Clinical Practice Guidelines (8th Edition). Chest. 2008;133(6 Suppl):381S-453S. http://dx.doi.org/10.1378/ chest.08-0656

28. Aito S, Pieri A, D'Andrea M, Marcelli F, Cominelli E. Primary prevention of deep venous thrombosis and pulmonary embolism in acute spinal cord injured patients. Spinal Cord. 2002; 40:300-03 http://dx.doi.org/10.1038/sj.sc.3101298

29. Merli GJ. Management of deep venous trombosis in spina cord injury. Chest.1992;102:652-7. http://dx.doi.org/10.1378/ chest.102.6_Supplement.652S

30. Barrwllier MT, Lezin B, Landy S, Le Hello C. révalence de la thrombose veineuse diagnostiquée par échographie-doppler des membres inférieurs dans la suspicion d'embolie pulmonaire et dans l'embolie pulmonaire confirmée. J Mal Vasc. 2001;26:23-30

31. Maffei FH. Trombose venosa profunda dos membros inferiores: incidência, patologia, fisiopatologia e diagnóstico. In: Maffei FH, Lastoria S, Yoshida WB, Rollo HA, editor. Doenças vasculares periféricas. São Paulo: Medsi; 2002. p. 1363-86.

32. Pitta GBB, Castro AA, Teixeira LR, Francisco J Jr, Miranda F Jr Burihan E. Preservação da veia safena magna na cirurgia das varizes tronculares primárias. J Vasc Bras. 2002;1(1):32-8. [citado 2011 abr. 20]. http://www.jvascbr.com.br/02-01-01/02-01-01-32/02 01-01-32.pdf.

33. Meissner MH. Dupplex follow-up of patients with DVT: does it have clinical significance? Semin Vasc Surg. 2001;14:215-21. http:// dx.doi.org/10.1053/svas.2001.25493

34. Zieler BK. Screening for acute DVT: optimal utilization of the vascular laboratory. Semin Vasc Surg. 2001;14:206-14. http:// dx.doi.org/10.1053/svas.2001.25492 
35. Zieler BK. Ultrasonography and Diagnosis of Venous Thromboembolism. Circulation. 2001;14:206-14. http://dx.doi. org/10.1161/01.CIR.0000122870.22669.4a

36. Kearon C. Natural history of venous tromboembolism. Circulation. 2003;107:22-30. http://dx.doi.org/10.1161/01. CIR.0000078464.82671.78

37. Sequeira CMG, Juliano $\mathrm{Y}$, Novo NF, Mayall RC, Miranda F Jr. Veias soleares: bases anatômicas e seu papel na origem da trombose venosa profunda em membro inferior. Rev Assoc Med Brás. 2007;53(4):305-10. http://dx.doi.org/10.1590/ S0104-42302007000400014

38. Melo REV, Silva C, Silva L, Melo M, Links E. Trombose venosa profunda. Int J Dent. 2006;1:73-79.
Correspondence Nelson Mesquita Junior Rua Deputado Heitor Alencar Furtado, 1819, apto. 1302 - Mossungue CEP 81200-110 - Curitiba (PR), Brazi E-mail:nelsonmesquita@terra.com.br

Author's information NMJ is professor in charge of the disciplines Anatomy I and II and Angiology and Vascular Surgery at Faculdade Evangélica do Paraná (FEPAR) and MSc in surgical practice from Universidade Federal do Paraná (UFPR)

FNMK and GLM are medical students at Faculdade Evangélica do Paraná (FEPAR).

FAFV is resident physician of neurosurgery at Hospital Universitário Evangélico de Curitiba (HUEC)

SFSM and SP are radiologist at Centro Paranaense de Ecocardiografia (CEPEC).

Author's contributions Conception and design: NMJ, FNMK, GLM Analysis and interpretation: NMJ, FNMK, GLM Data collection: NMJ, FNMK, GLM, FAFV, SFSM, SP Writing the article: NMJ, FNMK, GLM Critical revision of the article: NMJ, FNMK, GLM Final approval of the article*: NMJ, FNMK, GLM, FAFV, SFSM, SP Statistical analysis: NMJ, FNMK, GLM Overall responsibility: NMJ Obtained funding: By authors

*All authors should have read and approved of the final version of the article submitted to I Vasc Bras. 